\title{
ONZICHTBARE DRUPPELTJES, ONZICHTBAAR LICHT
}

\author{
De lucht van een hele ruimte steriliseren met behulp van ultraviolet \\ licht? In de eerste helft van de twintigste eeuw werden daarmee goede \\ resultaten behaald, maar alleen tijdelijk. Vandaag is hiervoor hernieuwde \\ belangstelling, niet in het minst voor de tandartspraktijken. door Frank Heynick
}

$\mathrm{H}$ et lijkt voor ons zo vanzelfsprekend, en helemaal in deze tijd van pandemie: bepaalde infectieziekten kunnen van mens tot mens (of van dier tot mens, enz.) via de lucht overgedragen worden. Maar in de laatste decennia van de negentiende eeuw - de glorietijd van de 'microbenjagers' - lag dat niet zo voor de hand. Een voor een werden de vectoren bij het verspreiden van infectieziekten en de verantwoordelijke pathogenen ontdekt. Maar pas in het laatste jaar van die eeuw publiceerde de Duitse bacterioloog Carl Georg Flügge zijn artikel 'Die Verbreitung der Phthise durch staubförmiges Sputum und durch beim Husten verspritzte Tröpfchen' (Phthise staat daarin voor tbc).

In de jaren dertig, veertig en vijftig van de twintigste eeuw werden op dit gebied grote vorderingen geboekt door de Amerikaan William Firth Wells, een excentrieke wetenschapper, die ook weleens psychotische aanvallen kreeg. Wells schreef onder andere over onzichtbare druppeltjes speeksel bij het uitademen en praten. Het vocht daarvan verdampt, maar de pathogenen blijven (als de persoon met bijvoorbeeld de griep geïnfecteerd is) een tijd in de lucht hangen.

\section{Zonlicht}

Hoe was deze verspreiding van ziekten via de lucht te bestrijden?
De Amerikaanse medisch-dentaal historicus dr. Frank Heynick heeft ruim vijfhonderd artikelen en een aantal boeken gepubliceerd. Alvorens in Groningen tot doctor in de geneeskunde te promoveren studeerde hij industriële vormgeving, geschiedenis, taalwetenschap en psychologie. Hij doceert aan de New York University.

Rond 1865 (dus vóór de ontdekkingen van Flügge en Wells) voerde de vermaarde Schotse chirurg Joseph Lister het antiseptische beleid in. Hierbij werden niet alleen handen, instrumenten en operatiewonden met carbolzuur ontsmet, dit middel werd ook in de operatiezaal in de lucht gesprayd. Maar Lister stopte ermee omdat deze nevel nadelig was voor de luchtwegen en longen van het medisch personeel en de patiënten.

William Wells had een alternatief voorstel: ziekenhuizen (en andere instellingen) met onzichtbaar licht desinfecteren.

$\mathrm{Al}$ in 1845 publiceerde de Oostenrijkse arts en natuurwetenschapper Ludwig Karl Schmarda zijn artikel 'Der Einfluss des Lichtes auf die Infusionsthierchen'. Deze benadering was nog weinig praktisch van aard, want de rol van micro-organismen bij overdraagbare ziekten had toen weinig aanhangers. Laat in de jaren zeventig van de negentiende eeuw, toen de ziektekiemtheorie in

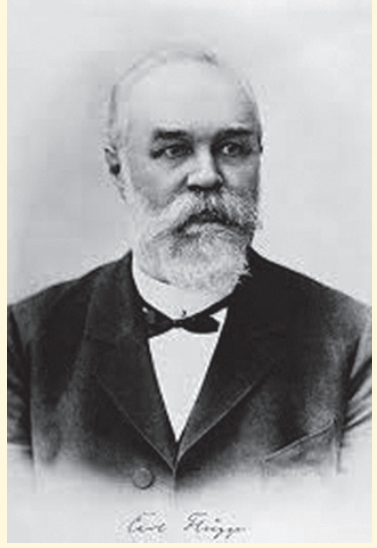

In 1899 publiceerde Carl Georg Flügge over besmetting door druppeltjes speeksel in de lucht.
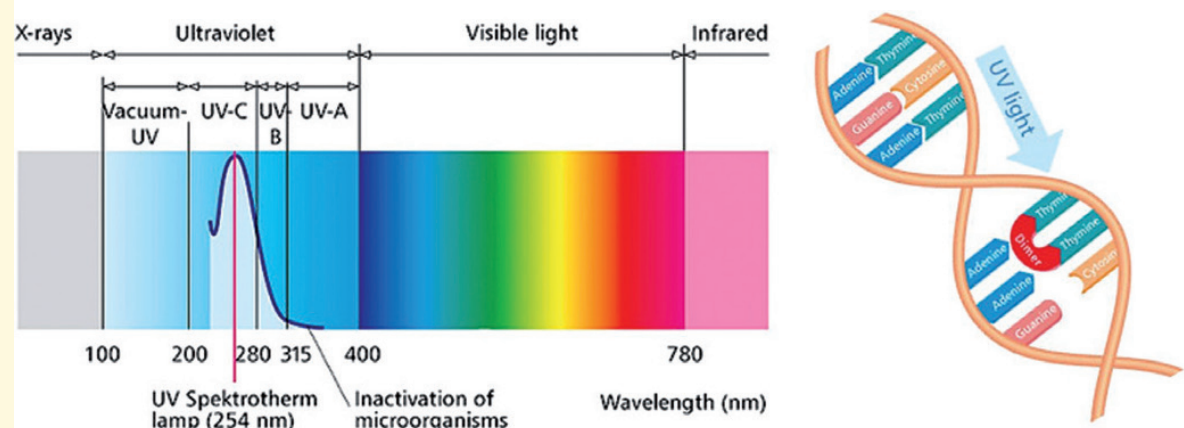

Het uv-licht maakt het DNA van de pathogeen kapot. Zo kan die zich niet vermenigvuldigen. 


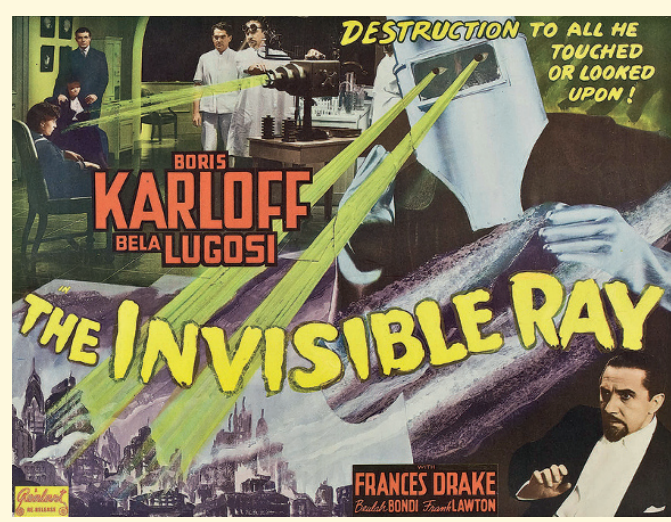

In de jaren 1930 werden onzichtbare stralen ook voor andere doeleinden gebruikt - althans op het witte doek.

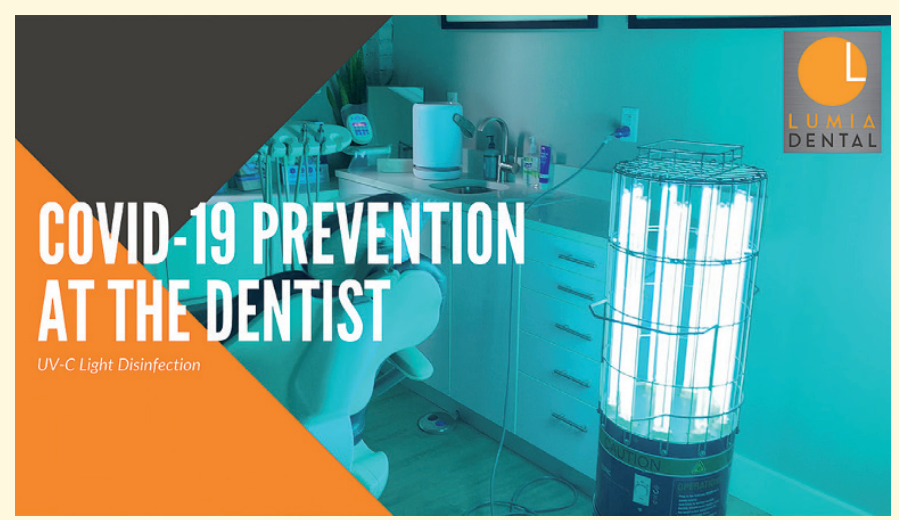

Reclame voor uv-apparaat op wieltjes. Het steriliserende licht is eigenlijk niet blauw maar onzichtbaar. opkomst was, lieten de Engelse medici Arthur Downes en Thomas Blunt een open reageerbuis met daarin een gesteriliseerde voedingsbodem uit het raam van hun laboratorium in Londen hangen. Tot hun verbazing bleef de inhoud in de onzuivere lucht wekenlang vrij van 'besmetting' door bacteriën en schimmels. De onderzoekers vermoedden dat het zonlicht daar iets mee te maken had.

Downes en Blunt voerden vervolgens nog een serie experimenten uit. Ze plaatsten in glazen bakken van verschillende kleuren open reageerbuizen met daarin gesteriliseerde voedingsbodems en zetten deze in het zonlicht. Merkwaardig genoeg groeiden in de reageerbuizen In de gele en rode glazen bakken wel microorganismen, maar niet in de blauwe. In hun publicaties over hun bevindingen speculeerden Downes en Blunt niet over ultraviolet licht. Toch was het bestaan daarvan al aan het begin van de eeuw bekend.

\section{Golflengte}

In 1801 splitste de Duitse natuurwetenschapper Johann Ritter met een prisma het zonlicht in zijn kleurenspectrum, om vervolgens de reactie (het donker worden) van zilverchloride bij blootstelling aan die verschillende kleuren te vergelijken. Het bleek dat hoe korter de golflengte - van rood tot paarsblauw - hoe sneller de reactie. Maar tot Ritters grote verbazing bleek de reactie des te sneller te zijn boven het paarsblauwe deel van het spectrum waar geen kleur was. Klaarblijkelijk bestond er onzichtbaar licht van nóg kortere golflengte.

Het was dus logisch dat men zich laat in de eeuw afvroeg: als uit de proeven van Downes en Blunt blijkt dat het paarsblauwe (violette) deel van het spectrum de sterkste werking tegen de groei van micro-organismen heeft, zou dan het onzichtbare licht - ultraviolet genoemd - een nóg sterkere werking hebben? Dit werd bevestigd in reageerbuizen en petrischaaltjes met antrax en een reeks andere pathogenen.

Maar wat dan te doen met de in de lucht hangende pathogenen van uitgedroogde druppeltjes speeksel die William Wells had aangetoond?

Vanaf de jaren 1930 gingen Wells en zijn collega's proeven uitvoeren aan de Universiteiten van Pennsylvania, Harvard en Duke, en een aantal ziekenhuizen met het bestralen van ruimtes met kunstmatig gegenereerd uv-licht. Omdat overmatige blootstelling aan uv-stralen schadelijk is voor de ogen en huid (zonnebrand, kanker), bestraalde Wells slechts het deel van een ruimte boven de hoofden van de mensen, en liet de gesteriliseerde lucht door de hele ruimte continu circuleren. Dit kon door ventilatoren of anders door verkoeling van het bovenste deel. (De koele lucht zakt continu naar beneden terwijl de warme lucht stijgt.)

\section{Apparaat}

Statistisch waren de resultaten van Wells imponerend bij het terugdringen van de incidentie van door de lucht verspreide tuberculose, mazelen en griep. Maar in de jaren daarop nam de belangstelling af. Tegen tbc werden antibiotica, zoals streptomycine, ontwikkeld en tegen mazelen en de griep vaccins. De uv-voorzieningen waren kostbaar en men was bezorgd om het risico van huidkanker bij te veel blootstelling aan uv-stralen (ook bij de nauwkeurig gerichte bovenruimtebestraling) en de mogelijke nadelen voor de luchtwegen en longen van vrijkomende ozon (hoewel ozon ook een steriliserende werking heeft).

Maar nu, met de covid-19-pandemie, is er weer grote belangstelling voor uv-apparaten voor het steriliseren van de lucht van medische en vooral tandartspraktijken. Gelukkig is de technologie met de tijd meegegaan. Er zijn apparaten die aan de muur of het plafond van de behandelkamer worden gemonteerd. Andere apparaten zijn verplaatsbaar; zo kan één toestel meer dan één behandelkamer bedienen. De bestraling duurt een paar minuten- meestal tussen de patiënten door - en geschiedt in de afwezigheid van het personeel (door afstandsbediening of een timer).

Andere apparaten, die de lucht inzuigen, binnen het apparaat met uv-licht steriliseren en dan uitblazen, mogen continu in gebruik zijn. Zo'n toestel (prijs 90 dollar) heb ik en paar jaar geleden voor mijn flat gekocht. Eigenlijk is het een luchtreiniger om de allergenen van mijn kat Timmy weg te filteren. Maar als ik op de uvtoets druk begint er aan de buitenkant een mooi blauw licht te flitsen, terwijl binnenin onzichtbare lichtstralen van veel kortere golflengte de pathogenen in de lucht kapotmaken. 